AL-IQTISHOD: Jurnal Pemikiran dan Penelitian Ekonomi Islam

E-ISSN: 2407-6600 P-ISSN: 2745-85I2

Volume I0 Issue I Januari 2022 | Page: 0I6-042 DOI: https://doi.org/I0.378I2/aliqtishod

\title{
Urgensi Sertifikasi Halal Food Dalam Tinjauan Etika Bisnis Islam
}

\author{
Mega Novita Syafitri \\ Universitas Muhammadiyah Sidoarjo, Sidoarjo, Indonesia \\ Email: meganovisy18@gmail.com \\ Rania Salsabila \\ Universitas Muhammadiyah Sidoarjo, Sidoarjo, Indonesia \\ Email: salsabilarania005@gmail.com \\ Fitri Nur Latifah \\ Universitas Muhammadiyah Sidoarjo, Sidoarjo, Indonesia \\ Email: fitri.latifah@umsida.ac.id
}

Abstract: The inclusion of halal label certification on food makes it an effective means for consumers to sort out halal food more easily and is a form of producer responsibility in doing business as well as protection for consumers. However, consumers have the right to know and get clear and detailed information about any composition or ingredients used in the manufacture of products that have been traded. This is also because the products circulating in the community are not necessarily safe, especially for Muslim consumers. Therefore, the purpose of this paper is to make producers and consumers aware of the importance of the inclusion of a halal label and halal certification in every product they circulate in the community. Then in writing this article the method used by the author is to use a qualitative method of literature study derived from various scientific works on the internet with discussions that are in accordance with the author's theme. And the results obtained from this paper are that the awareness of producers was initially very minimal and consumers also considered the halal label not too important. However, due to the large number of socializations about halal life, they are aware of the importance of halal certification of food products.

Keywords: Halal Certification, Halal Food, Islamic Business Ethics, Muslim Consumers Mention

Abstrak: Pencantuman sertifikasi label halal pada makanan menjadikan sebagai sarana yang efektif bagi konsumen untuk memilah makanan halal dengan lebih mudah dan merupakan sebagai salah satu bentuk tanggung jawab produsen dalam berbisnis serta perlindungan bagi konsumen. Bagaimanapun juga konsumen berhak untuk mengetahui dan mendapatkan sebuah informasi yang jelas dan rinci mengenai setiap komposisi atau bahan yang digunakan dalam pembuatan produk yang telah diperjual belikan. Hal tersebut juga dikarenakan produk-produk yang beredar dimasyarakat belum tentu aman terutama bagi konsumen muslim. Oleh karena itu tujuan dari penulisan ini yakni agar para produsen serta konsumen sadar akan pentingnya sebuah pencantuman label halal dan sertifikasi halal disetiap produk yang mereka edarkan dilingkungan masyarakat. Kemudian dalam penulisan artikel ini metode yang digunakan oleh penulis ialah 
menggunakan metode kualitatif studi pustaka yang berasal dari berbagai karya ilmiah di internet dengan pembahasan yang sesuai dengan tema penulis. Serta hasil yang diperoleh dari penulisan ini yakni kesadaran produsen awalnya sangat minim dan para konsumen juga menganggap label halal tidak terlalu penting. Namun, akibat banyaknya sosialisasi terhadap halal life membuat mereka melek terhadap pentingnya sertifikasi halal produk makanan.

Kata Kunci: Etika Bisnis Islam, Konsumen Muslim, Makanan Halal, Sertifikasi Halal 

Urgensi Sertifikasi Halal Food ...

\section{A. Pendahuluan}

Indonesia adalah sebuah negara yang didalamnya memiliki berbagai macam suku, budaya, dan juga agama. Keragaman tersebut disatukan dengan pedoman Indonesia yakni "Bhineka Tunggal Ika" yang dimana pedoman tersebut memiliki makna yang artinya

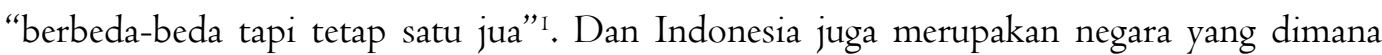
penduduknya mempunyai populasi umat muslim terbesar. Oleh sebab itu hal tersebut dapat menyebabkan meningkatnya sebuah produkfitas dan juga sebuah permintaan produksi yang bersifat halal yang ada di Indonesia. Contohnya adalah produksi halal food atau makanan yang berbasis halal, makanan merupakan sesuatu yang dimana berasal dari tumbuhan, hewan atau air yang kemudian diolah untuk sebagai makanan dan minuman yang kemudian dikonsumsi oleh manusia. Sedangkan makanan halal merupakan suatu makanan yang dimana prosesnya diolah dengan menggunakan bahan dari tumbuhan, hewan atau air yang hanya diperbolehkan dikonsumsi oleh umat muslim dan tidak mengandung unsur atau bahan tambahan makanan yang diharamkan dalam Al-Qur'an.

Oleh karena itu jaminan terhadap kehalalan sesuatu produk pangan dapat diciptakan dengan cara membentuk sertifikat halal yang dimana produk makanan tersebut harus menyertai label halal didalam kemasan suatu produk pangan, yang mana dengan sertifikasi halal tersebut seorang konsumen dapat melihat dan membedakan produk halal dengan yang non halal dengan begitu umat islam akan terhindar dan tidak merugikan umat Islam. Penjelasan UU Nomor I8 pada tahun 2012 yang dimana didalamnya membahas tentang pangan mengatakan bahwa pangan merupakan kebutuhan dasar manusia yang paling utama dan pemenuhannya merupakan bagian dari hak asasi setiap rakyat Indonesia ${ }^{2}$. Yang didamana pasal tersebut secara runtut menjelaskan bahwa segala sesuatu yang berasal dari hayati produk yang diambil berasalkan dari pertanian, perkebunan, perhutanan, perikanan, dan juga peternakan, yang kemudian diolah atau juga bisa produk tersebut tidak

\footnotetext{
${ }^{\text {I }}$ Ahmad Izzuddin, "Pengaruh Label Halal. Kesadaran Halal Dan Bahan Makanan Terhadap Minta Beli Makanan Kuliner," Jurnal Penelitian Ipteks 3, no. 2 (2018): I00-I I4.

${ }^{2}$ KN. Sofyan Hasan, "Kepastian Hukum Sertifikasi Dan Labelisasi Halal Produk Pangan,” Dinamika Hukum I4, no. I00 (2013): 227-38.
} 
diolah yang digunakan sebagai makan dan juga minum untuk dikonsumsi oleh umat manusia, dan bahan tambahan pangan, bahan baku pangan dan bahan lain yang digunakan dalam proses menyiapkan, mngelola, atau membuat makanan atau minuman.

Ada juga UU yang membahas tentang peraturan didalam Undang-Undang kehalalan suatu produk. Undang-Undang yang dimaksud tersebut adalah UU Nomor 33 Tahun 2014 tentang Jaminan Produk $\mathrm{Halal}^{3}$. Dalam suatu kehalalan dalam produk tersebut menjadi suatu kebutuhan yang keharusan bagi untuk umat muslim, baik hal tersebut berupa pangan, obat-obatan maupun barang-barang yang akan digunakan. Produk yang bersifat halal tidak hanya diminati atau disukai oleh kalangan masyarakat muslim namun pati juga akan diminai oleh masyarakat non-muslim, dikarenakan makanan yang bersifat halal tersebut sudah dipastikan sehat. Sebuah perlindungan yang diberikan kepada seorang konsumen adalah salah satu kegiatan yang tidak dapat dipisahkan oleh sebuah kegiatan yang dimana kegiatan tersebut berhubungan dengan bisnis yang sehat. Didalam sebuah kegiatan yang berhubungan dengan jalannya bisnis yang dibilang sehat, pasti didalamnya juga terdapat keseimbangan perlindungan dari hukum antara konsumen dan juga produsen. Dalam permasalahan yang membahas perlindungan konsumen pasti tidak akan tuntas dan pasti juga akan menjadi pokok bahan pembicaraan dikalangan masyarakat. Ketika masih banyak konsumen yang masih dirugikan, maka masalahnya tidak akan pernah tuntas.

Oleh sebab itu, permasalahan mengenai perlindungan konsumen masih perlu diperhatikan. Hak terhadap pelanggan atau konsumen yang tidak dipedulikan oleh para pelaku usaha perlu dicermati dan diawasi secara seksama. Pada era globalisasi seperti saat ini sebuah perkembangan pada perekonomian yang terutama ada dibidang perindustrian dan perdagangan nasional sekarang, telah menghasilkan berbagai bentuk barang dan jasa

\footnotetext{
${ }^{3}$ Melissa Aulia Hosanna dan Susanti Adi Nugroho, "Pelaksanaan UU Nomor 33 Tahun 2014 Tentang Jaminan Produk Halal," Hukum Adigama, 2014.
} 


\section{Urgensi Sertifikasi Halal Food ...}

yang dapat dikonsumsi ${ }^{4}$. Tapi diposisi lain produk kebutuhuan hidup mulai dari makanan, kosmetik, obat-obatan yang telah disebar luaskan oleh para pelaku usaha dibidang tersebut harus memunyai rasa tanggung jawab yang tinggi kepada produk-produk yang telah disebarkan.

Dan kalangan masyarakat juga berhak untuk mengetahui dan mendapatkan sebuah informasi yang jelas dan rinci mengenai setiap komposisi atau bahan yang digunakan untuk produk yang disajikan didalam produk tersebut. Sebelum membeli dan mengkonsumsi produk tersebut Informasi mengenai asal bahan yang digunakan, keamanan, mutu, kandungan gizi, sampai keterangan lain yang diperlukan sehingga masyarakat dapat mengambil keputusan berdasarkan informasi yang benar dan akurat ${ }^{5}$. Dikarenakan produk yang telah lebel halal atau bersertifikat halal tersebut sudah menjadi kewajiban yang dimana hal tersebut tidak dapat dipisahkan dari sebuah kegiatan penjualan, perdagangan dan juga ekonomi yang sudah sampai global yang sudah memenuhi sebuah kualliats-kualitas baku Internasional yang bertujuan untuk mendapatkan sebuah amanah atau kepercayaan dari pelanggan atau seorang konsumen dari lintas negara. Dengan demikian hal produksi atau aliran sebuah barang, jasa, modal dan juga ilmu pengetahuan antar luar negara menjadi semakin mudah. Dikarenakan perdagangan yang sudah sampai Go-Internasional akan memiliki sebuah pengaruh besar terhadap perekonomian antar negara yang telah bekerja sama.

\section{B. Kajian Pustaka}

\section{Sertifikasi Terhadap Produk Halal Food}

Sertifikasi tentang kehalalan produk dengan labelisasi adalah dua hal yang berbeda akan tetapi saling memiliki berhubungan. Sertifikasi halal merupakan sebuah surat keterangan yang dimana dikeluarkan oleh Majlis Ulama Indonesia atau biasa dekenal dengan sebutan MUI pusat atau Majlis Ulama Indonesia bagian provinsi yang

\footnotetext{
${ }^{4}$ Aulia Hosanna dan Adi Nugroho.

${ }^{5}$ Warto dan Samsuri, "Sertifikasi Halal dan Implikasinya Bagi Bisnis Produk Halal di Indonesia," Al Maal: Journal of Islamic Economics and Banking 2, no. I (2020): 98-II2.
}

I8| Al-Iqtishod Volume. IO/No. I/Januari 2022 
membahas tentang suatu kehalalan pada produk makanan, minuman, kosmetika dan bisa pada produk obat-obatan yang diproduksi oleh perushaan yang telah diteliti atau diamati dan kemudian telah dinyatakan halal oleh LPPOM MUI. Dilakukan sertifikasi halal pada produk makanan, kosmetik, minuman, dan obat-obatan dengan tujuan untuk memberikan sebuah kepastian terhadap kehalalan didalam produk, jadi ketika produk tersebut digunakan oleh konsumen maka konsumen akan tentram dan tidak gelisah tentang kehalalan pada suatu produk tersebut.

Di dalam produk halal menandung syarat yang harus dipenuhi agar mendapatkan labelisasi dan sertifikasi kehalalan terhadap produk yang diedar, syarat yang pertama adalah: I) Makanan atau produk yang diedar tidak mengandung unsur babi, 2) Produk yang akan diedar tidak mengandung unsur dari bahan-bahan yang telah diharamkan seperti halnya bahan-bahan yang berasal dari organ manusia seperti; darah, kotoran dan lain-lain ${ }^{6}$. Kemudian syarat yang ke 3) Adalah hewan-hewan yang telah disembelih dengan syariat islam dan tidak lupa menyebbut nama Allah, 4) Semua mulai dari tempat menyimpan, menjual, mengelolah, kemudian tempat untuk mengelola tidak dianjurkan untuk babi, namun jika pernah dipakai oleh babi atau barang yang tidak diperbolehkan lainnya maka sebaiknya dibersihkan terlebih dahulu sesuai apa yang telah diataur dalam syariat islam jika sebelum menggunakannya.

Sedangkan labelisasi kehalalan merupakan mencantumkan sebuah tulisan atau sebuah pernyataan tentang kehalalan pada suatu produk dalam kemasan dengan tujuan untuk menunjukkan jika produk tersebut aman untuk umat islam dengan ditandai sebagai produk halal. Kegiatan pada labelisasi kehalalan yang diolah oleh Badan Pengawas Obat dan juga Makanan atau biasa dikenal dengan sebutam BPOM.didalam UU No. 7 pada tahun 1996 yang isinya tentang pangan yang dimana peraturannya

\footnotetext{
${ }^{6}$ Ramlan dan Nahrowi, "Sertifikasi Halal Sebagai Penerapan Etika Bisnis Islami Dalam,” Ahkam I4, no. 7 (I996): I45-54.
}

Volume. I0/No. I/Januari 2022 A1-Iqtishod | I9 


\section{Urgensi Sertifikasi Halal Food ...}

yang dimuat dengan pencantuman label pada pangan yang telah dikemas mengandung keterangan kehalalan pada produk.

Sedangkan pemegang otoritas menerbitkan atau mengeluarkan setifikasi produk halal adalah MUI yang secara teknis ditangani oleh Lembaga Pengkajian Pangan, Obat-obatan, dan Kosmetika (LPPOM) ${ }^{7}$. Dikarenakan untuk konsumen serifikasi halal tersebut memiliki beberapa fungsi diantaranya sebagai berikut yang pertama, untuk konsumen umat muslim dapat terlindungi ketika mengonsumsi makanan, kosmetik, minuman, dan obat-obatan yang ada unsur keharaman, kemudian yang kedua, secara hati nurani atau perasaan konsumen akan tenang.

Sedangkan untuk produsen sertifikat halal tersebut memiliki beberapa peran yang sangat penting diantaranya sebagai tanggung jawab seorang produsen terhadap konsumen yang beragama muslim dikarenakan mengenai kehalalan tentang makanan adalah bagian dari pedoman hidup umat muslim, yang kedua meningkatkan kepercayaan dan kepasaan terhadap konsumen, lalu peran ketiga, meningkatkan citra dan daya saing perusahaan dan keempat, sebagai alat pemasaran serta untuk memperluas area jaringan pemasaran ${ }^{8}$.

Di Indonesia kini sudah banyak kasus atau permasalahan tentang kehalalan produk maka dari itu Majelis Ulama Indonesia atau MUI kini belajar dari pengalaman kasus atau peristiwa yang telah terjadi. Oleh karena itu Majlis Ulama Indonesia (MUI) berusaha melakukan perannya untuk mendamaikan dan memberikan solusi kepada umat islam mengenai masalah kehalalan produk pangan dengan cara mendirikan lembaga pengkajian pangan, obat-obatan dan kosmetika MUI (LPPOM MUI) yang bertugas untuk melakukan pengkajian kehalalan produk pangan, obat dan kosmetika9 . Sebagaimana upaya yang telah dilakukan untuk memberikan sebuah kepastian kepada masyarakat tentang kehalalan pada produk makanan maka dari itu LPPOM MUI memulai sebuah penrgerakan kegiatan sertifikasi kehalalan makanan pada tahun 1994.

\footnotetext{
${ }^{7}$ Hasan, "Kepastian Hukum Sertifikasi Dan Labelisasi Halal Produk Pangan.”

${ }^{8}$ Ibid.

9 Ainol Yakin, "Pencantuman Label Halal (Halal Food) Etika Dalam Bisnis Dan Perlindungan Konsumen," Ekomadania 2, no. I (2018): 24-34.
} 
Namun pada saat itu pergerakan tersebut mengalami kendala dikarenakan oleh pihak pemerintah, kemudian pihak Departemen Kesehatan dan Departemen Agama yang dimana sebagai pihak yang merasa memiliki sebuah tanggung jawab dalam sebuah pegawasan terhadap peraturan produk makanan dan berkaitan dengan kehalalan terhadap makanan sekaligus, merasakan berhak untuk melakukan lebelisasi atau sertifikasi kehalalan terhadap makanan.

Setelah melakukan berbagai macam pertemuan dan juga membahas tentang kehalalan produk maka terwujudlah temuan dimana permasalahan tentang sertifikasi atau lebelilisasi mengenai makanan halal yang dimana akan ditanda tangani oleh ketiga lembaga yaitu MUI, Departemen Kesehatan, dan Departemen Agama dimana ketiga lembaga tersebut menandatangani SKB atau surat keputusan bersama ${ }^{10}$. Dengan adanya lebel halal tersebut menunjukkan bahwa peristiwayang sangat penting karena tidak hanya memberikan tanda akan kesadaran terhadap nilai-nilai etika dalam berdagang, namun juga menunjukkan jika produsen peduli terhadap kemaslahatan konsumen terutama pada umat muslim.

Label halal yang mengandung sebuah aspek yuridis untuk memberikan sebuah perlindungan konsumen. Yang artinya secara hukum mencantumkan sebuah label halal yang berarti melindungi konsumen dan melaksanakan undang-undang perlindungan konsumen ${ }^{11}$. Pada Produk makanan yang telah banyak diedarkan diIndonesia tersebut sangat penting jika produk tersebut mendapatkan nama produk dan label yang menunjukkan kehalalan suatu produk dari badan yang menyelenggarakan jaminan Produk Halal, dikarenakan konsumen pastinya akan memahami ketika produk tersebut benar-benar terjamin tentang kehalalannya. Terlebih lagi jika mencamtukan label halal diberikan kepada masyarakat yang beragama muslim agar terhindar dari produk yang tidak halal. Tidak hanya itu dengan adanya sebuah labelisasi pada produk dapat

\footnotetext{
${ }^{10}$ Ibid.

${ }^{\text {II }}$ Aulia Hosanna dan Adi Nugroho, "Pelaksanaan UU Nomor 33 Tahun 2014 Tentang Jaminan Produk Halal."
}

Volume. I0/No. I/Januari 2022 A1-Iqtishod|2I 


\section{Urgensi Sertifikasi Halal Food ...}

digunakan sebagai tanda bahwa produk tersebut halal dan juga memudahkan pembeli untuk membeli produk yang akan dikonsumsi maupun produk yang akan dipakai oleh konsumen.

\section{Etika Bisnis Islam}

Etika tidak hanya diterapkan kepada orang-orang yang kita kenal saja, akan tetapi dalam dunia bisnis dan pekerjaan etika juga sangatlah penting penerapannya. Dengan beretika maka hidup kita akan teratur dengan baik dan selalu terjaga dan terlindungi dari hal-hal buruk yang bertentangan dengan adat kebiasaan maupun hak-hak asasi dalam bermasyarakat. Maka dari itu kita perlu memahami terlebih dahulu dasar dari kata etika bisnis Islam. Dalam bahasa Yunani Kuno, etika berasal dari kata ethikos yang memiliki arti "timbul dari kebiasaan" atau bisa diartikan dengan norma-norma, nilai-nilai, kaidah-kaidah dan ukuran-ukuran bagi tingkah laku manusia yang baik. Secara umum etika adalah tingkah laku atau perbuatan dari seseorang maupun kelompok masyarakat dimana hal tersebut sudah biasa dilakukan pada aktifitas seharihari yang berhubungan dengan nilai-nilai kehidupan.

Etika merujuk pada teori bagaimana seharusnya kita memikirkan dan bertindak mengenai hal yang baik atau buruk dan salah atau benar. Etika bukan hanya laranganlarangan normatif, tetapi lebih merupakan puncak akumulasi kemampuan operasionalisasi intelegensi manusia ${ }^{12}$. Dari beberapa penjelasan mengenai pengertian etika diatas maka dapat disimpulkan bahwa etika merupakan suatu perilaku pada setiap individu yang tercipta pada akal kita karena kebiasaan dari masyarakat sekitar ataupun pergaulan dimana dalam beretika kita mempelajari mengenai nilai-nilai ataupun norma masyarakat, yang nantinya akan kita terapkan dalam suatu kegiatan dimana dapat menimbulkan sifat baik maupun buruk.

Kata bisnis secara historis dari bahasa Inggris yaitu business, dari kata dasar busy yang berarti "sibuk" dalam konteks individu, komunitas, ataupun masyarakat. Dalam

\footnotetext{
${ }^{12}$ Erly Juliyani, “Etika Bisnis Dalam Persepektif Islam,” Jurnal Ummul Qura VII, no. I (2016): 63-74.
} 
artian, sibuk mengerjakan aktivitas dan pekerjaan yang mendatangkan keuntungan. Sedangkan secara etimologi, bisnis berarti keadaan dimana seseorang atau sekelompok orang sibuk melakukan pekerjaan yang menghasilkan keuntungan. Secara bahasa, bisnis mempunyai beberapa arti; usaha, perdagangan, toko, perusahaan, tugas, urusan, hak, usaha dagang, usaha komersial dalam dunia perdagangan atau bidang usaha. Dari beberapa pengertian tersebut dapat disimpulkan bahwa bisnis merupakan aktifitas perekonomian yang cakupannya sangat luas dimana didalamnya terdapat berbagai aktifitas pekerjaan yang terorganisir serta tentunya hal tersebut dilakukan untuk mendapatkan sebuah penghasilan dan keuntungan.

Pada dasarnya bisnis atau muamalah dalam pandangan Islam dengan umum sama, hanya saja bisnis dalam Islam harus dijalankan sesuai dengan ketentuan hukum Islam. Islam menekankan agar aktivitas bisnis tidak hanya dijadikan sebagai pemuas atas keinginan memperoleh keuntungan semata, akan tetapi dijadikan sebagai upaya menciptakan kehidupan yang seimbang dan adil antara pembeli dan penjual. Bisnis harus dikendalikan dalam batas-batas yang jangan sampai merusak kebebasan dan kesehatan setiap konsumen atau masyarakat secara keseluruhan ${ }^{13}$. Pedagang haruslah memiliki rasa tanggung jawab lebih yang tidak terlepas hanya untuk memenuhi kebutuhan pembeli saja, namun dengan tanggung jawab lebih dengan menjual produk yang halal sesuai dengan hukum Islam. Hal tersebut dengan cara tidak mencurangi pembeli dengan menjual produk-produk yang mengandung zat-zat berbahaya, bahkan dari bahan-bahan yang haram dalam pembuatannya. Oleh sebab itu, peran pedagang sangatlah penting dengan mengeban tanggung jawab yang cukup besar.

Namun semakin banyaknya pesaing di dunia bisnis menjadikan para pedagang memutar otak agar bisnisnya tetap jaya, akan tetapi strategi yang mereka ambil telah melampaui batas etika hukum Islam dan mengabaikannya. Perilaku-perilaku tersebut

\footnotetext{
${ }^{13}$ Rahmawati, "Etika Bisnis Islam Pada Pedagang Makanan (Studi Kasus di Keude Blang Jreum, Aceh)," Jurnal JESKaPe I, no. I (2017): I09-36.
}

Volume. IO/No. I/Januari 2022 A1-Iqtishod |23 


\section{Urgensi Sertifikasi Halal Food ...}

seringkali dilakukan oleh para pedagang salah satunya dengan pengoplosan bahanbahan kualitas bagus dengan bahan yang busuk, kemudian mengurangi takaran dari timbangan dan lain sebagainya. Dalam kode etik pada perdagangan Islam haruslah berpedoman pada ajaran-ajaran Rasul yaitu shidiq (jujur), amanah, tidak mengandung riba, tidak melakukan penipuan, tidak menjelekkan pesaing lainnya, tidak menimbun suatu produk, menepati janji, tidak merugikan orang lain, dan lain-lain.

Dari sini dapat kita lihat bahwa etika dengan bisnis memiliki keterkaitan dengan satu sama lain. Dalam berbisnis perlu adanya etika yaitu cara kita mengetahui apakah yang akan kita lakukan benar atau salah. Dalam pandangan Islam etika bisnis merupakan sebuah nilai-nilai dari etika Islam dalam kegiatan berbisnis dimana penerapannya sesuai dengan prinsip-prinsip ajaran Islam yang bersumber dari AlQur'an dan As-Sunnah. Prinsip-prinsip dasar etika bisnis Islam ada lima, yaitu kesatuan (unity), keseimbangan (equilibrium), kehendak bebas (free will), tanggungjawab (responsibility) dan kebenaran: kebajikan dan kejujuran ${ }^{14}$.

Dalam prinsip kesatuan meyakini kita bahwa segala kegiatan ekonomi dalam hal harta benda merupakan milik Allah SWT dan seluruhnya ialah berada di kehendakNya. Kemudian pada prinsip keseimbangan dimana segala sesuatunya tidak ada pihak yang dirugikan dan saling ridho. Prinsip kehendak bebas memiliki artian bahwa semua individu berhak mengambil semua tindakan untuk memperoleh kemaslahatan demi mencapai kesejahteraan hidup, namun tentunya dengan adanya batasan nilai Islam. Selanjutnya prinsip tanggung jawab yang mana setelah semua tindakan yang telah diambil oleh pelaku bisnis tentunya harus dipertanggung jawabkan baik dalam hal bertransaksi, memproduksi, menjual produk, jual beli, dan melakukan perjanjian dengan konsumen. Dan prinsip yang terakhir yaitu kebenaran atau kejujuran dimana hal ini yang paling utama agar membangun kepercayaan dari konsumen untuk tetap membeli atau memakai produk kita.

\footnotetext{
${ }^{\text {I4 }}$ Silma Nur Assifa, Titin Suprihatin, dan Nanik Eprianti, "Tinjauan Prinsip Etika Bisnis Islam pada Strategi Pemasaran di Restoran Royal Kashimura Bandung," Prosiding Hukum EKonomi Syariah 6, no. 2 (2020): 205-8.
} 
Prinsip-prinsip tersebut mengantarkan kita dengan batas-batas aturan apa saja yang dapat kita lakukan dan batas mana saja yang tidak boleh kita langgar. Etika bisnis Islam mengajarkan kita untuk mengambil sesuatu yang berlebihan dapat berdampak buruk, sama halnya dengan pengambilan suatu laba yang mana dapat menjurus ke pengeksploitasian suatu produk hingga mengganggu fungsi pasar. Pada hakikatnya tujuan penerapan aturan (syariah) dalam ajaran Islam di bidang muamalah tersebut khususnya perilaku bisnis adalah agar terciptanya pendapatan (rizki) yang berkah dan mulia, sehingga akan mewujudkan pembangunan manusia yang berkeadilan dan stabilisasi untuk mencapai pemenuhan kebutuhan, kesempatan kerja penuh dan distribusi pendapatan yang merata tanpa harus mengalami ketidakseimbangan yang berkepanjangan di masyarakat ${ }^{15}$. Penerapan etika bisnis Islam haruslah dilaksanakan secara menyeluruh sejak dari produksi barang, pendistribusian, hingga konsumsi.

\section{Metode Penelitian}

Penulisan ini menggunakan metode kualitatif dengan teknik systematic literature review, dimana sumber data berasal dari berbagai karya ilmiah artikel, jurnal, dan buku yang berisikan hasil tulisan ilmiah maupun penelitian sesuai fakta di lapangan dari internet yang berhubungan dengan tema tulisan yang telah dibahas. Setelah mendapatkan karya ilmiah sesuai tema, langkah selanjutnya melakukan analisis data dengan memilah, mengidentifikasi, dan memfokuskan pada hal-hal yang penting saja dan selanjutnya akan di sajikan dalam bentuk data yang telah difahami dan melakukan penarikan kesimpulan.

\footnotetext{
${ }^{15}$ Fitri Amalia, "Etika Bisnis Islam: Konsep Dan Implementasi Pada Pelaku Usaha Kecil," Al-Iqtishad: Jurnal Ilmu Ekonomi Syariah 6, no. I (2014): II6-25.
}

Volume. I0/No. I/Januari 2022 A1-Iqtishod|25 
Urgensi Sertifikasi Halal Food...

\section{Hasil dan Pembahasan}

\section{a) Standarisasi MUI atau BPOM yang Merujuk Sektor Halal Food}

Sebuah pemasalahan atau isu yang sering muncul dikalangan masyarakat mengenai produk yang bersifat makanan atau produk minuman yaitu isu atau permasalahan yang mengandung tidak adanya standarisasi yang sesuai menurut Majelis Ulama Indonesia (MUI) dan Badan Pengawas Obat dan Makanan (BPOM). Maka dari itu sebuah hal yang dituntut konsumen adalah akan adanya sebuah produk yang benarbenar produk halal yang mengandung bahan yang terjamin gizinya dan produk tersebut juga higienis pada saat proses pembuatannya, tak hanya itu hal yang perlu diperhatikan juga adalah bahan yang digunakan hanya diperbolehkan oleh islam atau Al-Qur'an. Jadi pada lebel halal pada makanan atau minuman merupakan sebuah kewajiban pada produk agar konsumen juga mengerti apakah produk tersebut dapat dikonsumsi atau tidak dapat dikonsumsi.

Untuk yang dimaksud dengan sertifikasi halal adalah sebuah fatwa yang dimana sudah tertulis MUI (Majelis Ulama Indonesia) yang telah dinyatakan pada kehalalan suatu produk sesuai dengan syariat Islam ${ }^{16}$. Jadi sertifikasi halal tersebut adalah sebuah syarat untuk memberikan sebuah lebel halal pada produk sehingga produk tersebut dapat dikonsumsi oleh masyarakat beragama Islam. Dan para pedagang harus melaksanakan sebuah syarat tersebut dan juga melakukan sebuah proses yang telah diatur oleh Majelis Ulama Indonesia untuk mendapatkan sertifikasi halal pada produk yang dipasarkan. Setelah melewati beberapa proses yang diatur oleh Majelis Ulama Indonesia dan kemudian telah diputuskan tentang kehalalan produk, maka dibuatkan sebuah keputusan fatwa secara tertulis yang telah ditetapkan fatwa pada umumnya untuk produk yang akan dipasarkan. Kemudian pedagang mendapatkan sebuah sertifikasi halal, setelah para pelaku usaha telah mendapatkan sertifikasi halal para

${ }^{16}$ Elfirda Ade Putri, "Kewenangan MUI Pasca Terbitnya PP No . 31 Tahun 2019 Tentang Peraturan Pelaksanaan UU No. 33 Tahun 2014 Tentang Jaminan Produk Halal” I5, no. 2 (202I): 333-50. 
pelaku usaha tersebut akan mendapatkan sebuah label halal untuk produknya dari Majelis Ulama Indonesia untuk mencantumkan label halal pada produknya.

Kemudian para pengendali sertifikasi halal Majelis Ulama Indonesia akan bertanggung jawab untuk merawat atau memelihara sebuah kehalalan pada produk yang akan diproduksi, kemudian sertifikasi halal tersebut tidak dapat dipindah namakan atau pindah tangan ke orang lain. Pada dasarnya dalam sebuah UU NO. 33 Tahun 2014 yang dimana menjelaskan tentang kejaminan suatu produk halal. Yang masih menjadi perdebatan dikarenakan proses yang dibutuhkan akan sangat panjang yang persis menjadi bahan pembicaraan di masyarakat pelaku bisnis terutama media massa. Dikarenakan dinegara indonesia kini mayoritas penduduk beragama Islam dan tentang kehalalan suatu produk akan menyangkut tentang kehidupan warga negara tak hanya itu sertifikasi kehalalan pada suatu produk akan menjadi sorotan. Saat 2006 DPR berinisiatif untuk mengusulkan Undang-Undang tentang jaminan produk halal tetapi masih belum diselesaikan pembahasannya sampai akhir tugas priode tahun 2009-20I4 yang membahas mengenai jaminan produk halal. Dan pada akhirnya presiden mengesahkan jaminan produk halal tersebut pada tahun 2014.

Adapun peraturan kepala BPOM (Badan Pengawasan Obat dan Makanan) Nomor I2 tahun 2016 yang dimana membahas tentang Pendaftaran Pangan Olahan, sehingga makanan yang diolah kemudian akan didaftarkan kehalalannya harus memenuhi sebuah kriteria keamanan, mutu, dan gizi ${ }^{17}$. Sebuah tatanan praktik didalam Indonesia dalam upaya memberikan sebuah perlindungan atau pertahanan untuk konsumen terutama terhadap konsumen yang beragama Islam dinyatakan melalui SK (Surat Keputusan) Menteri Agama Nomor 5 I8 pada tanggal 30 bulan November yang dimana membahas tentang bagaimana cara untuk memeriksa dan menetapkan makanan yang sudah teruji kehalalannya. Tetapi pemerintah akan berusaha untuk mengembalikan dan juga menerapkan sebuah lebelisasi pada produk yang halal

\footnotetext{
${ }^{17}$ Rahmawati, "Etika Bisnis Islam Pada Pedagang Makanan (Studi Kasus di Keude Blang Jreum, Aceh).”
} 


\section{Urgensi Sertifikasi Halal Food ...}

terhadap produk makanan maupun produk minuman. Lembaga yang melaksanakan sebuah pemeriksaan kepada produk makanan atau minuman yang telah dinyatakan kehalalannya kemudian produk tersebut dikemas untuk diperdagangkan hal tersebut dilakukan oleh Majelis Ulama Indonesia (MUI). Tidak hanya itu Surat Keputusan (SK) Nomor 525 Tahun 200I yang dimana menjelaskan bahwa kementrian Agama yang merujuk kepada Peruri (Perum Percetakan Ulang Republik Indonesia) yang dimana tugasnya untuk mencetak sebuah lebel halal yang akan diberikan langsung kepada produk-produk yang telah dinyatakan oleh Majelis Ulama Indonesia.

Untuk menghargai pendapat dan hak masyarakat Islam maka perlu dilakukan jaminan kehalalan terhadap produk-produk makanan dan minuman. Tetapi tentang kehalalan suatu produk tidak dapat dikatakan sendiri oleh produsen, harus dinyatakan oleh Majelis Ulama Indonesia dan Badan Pengawas Obat dan Makanan karena harus melakukan rangkain proses pemeriksaan secara menyeluruh oleh lembaga yang memiliki kewenangan terhadap proses pemeriksaan suatu produk. Kemudian keputusan untuk suatu produk tentang kehalalannya dinyatakan oleh komisi Fatwa MUI (Majelis Ulama Indoesia). Pada dasarnya Indonesia merupakan negara yang memiliki penduduk dengan mayoritas masyarakatnya beragama Islam, oleh karena itu sudah seharusnya pemerintah dan para pelaku bisnis usaha untuk memberikan suatu kenyamanan kepada para konsumen yang mengkonsumsi suatu produk makanan.

Pada dasar Badan Pengawas Obat dan Makanan mempunyai sebuah kewenangan yang secara sah sebagai badan pemerintah. Namun Majelis Ulama Indonesia tersebut mengatakan sebuah perlawanan dengan menyatakan bahwa Badan Pengawas Obat dan Penagwas kurang baik dalam pengerjaannya dalam mengeluarkan sebuah sertifikasi halal ${ }^{18}$. Oleh karena itu Majelis Ulama Indonesia sangat khawatir terhadap Badan Pengawas Obat dan Makanan yang didalamnya berisi biokrat dan dimana tidak terlalu memahami tentang hukum kehalalan dan haram yang dimana lebih memperdulikan

\footnotetext{
${ }^{18}$ Suad Fikriawan, "Sertifikasi Halal Di Indonesia: (Analisis Kuasa Simbolik dalam Kontestasi Fatwa Majelis Ulama Indonesia)," el Barka: Journal of Islamic Economics and Business OI, no. OI (2018): 27-52.
} 
tentang kesehatan daripada memperdulikan semua kepentingan umat muslim tentang halal dan haramnya suatu produk.

Menurut Majelis Ulama Indonesia didalam UU No. 7 Tahun 1996 yang dimana tentang pangan menjelaskan bahwa pasal tersebut menyatakan bahwa pangan yang telah diproduksi maupun diimpor ke dalam Indonesia harus mempunyai lebel yang menunjukkan kehalalannya, dengan pernyataan tersebut Undang-Undang tersebut menjadi bahan pembelaan Majelis Ulama Indonesia terhadap kewenangannya. Tetapi sebelum adanya Undang-Undang tentang pangan, presiden Soeharta telah menyampaikan dan juga telah mengeluarkan Inpres No. 2 Tahun I99I yang dimana membahas tentang makanan yang mengandung kehalalannya. Hal tersebut disampaikan oleh Soeharto kepada Menteri Koordinator Kesajahteraan Rakyat.

Dengan intruksi yang telah diberikan oleh presiden tersebut, tugas tersebut dipindahkan ke tujuh menteri yang dimana didalamnya termasuk Departemen Agama (Depag) dan Departemen Kesehatan (Depkes) serta termasuk delapan gubernur. Yang dimana memrujuk kepada Inpres tersebut yaitu makanan yang sudah terjamin kehalalannya akan berada dibawah naungan Menteri Koordinator Kesejahteraan Rakyat, kemudian Menteri Koordinator Kesejahteraan Rakyat merujuk kepada Majelis Ulama Indonesia untuk mengeluarkan sebuah sertifikasi halal untuk suatu produk.

Sertifikasi halal ini bertujuan untuk memudahkan dan memberikan informasi kepada masyarakat yang akan mengonsumsi produk tersebut bahwa produk yang telah dikemas tersebut benar-benar produk yang aman untuk dikonsumsi, tidak hanya itu sertifikasi kehalalan pada produk juga sebagai salah satu bentuk perlindungan kepada konsumen terhadap kehalalan suatu produk $^{19}$. Sebuah sertifikasi halal yang telah ditulis oleh Majelis Ulama Indonesia maka sebuah produk tersebut telah teruji

\footnotetext{
${ }^{19}$ Muthia Sakti, Dwi Aryanti R, dan Yuliana yuli W, "Perlindungan konsumen terhadap beredarnya makanan yang tidak bersertifikat halal,” Yuridis 2, no. I (20I5): 62-77.
}

Volume. IO/No. I/Januari 2022 Al-Iqtishod|29 
Urgensi Sertifikasi Halal Food ...

kehalalannya oleh Majelis Ulama Indonesia dan sertifikasi tersebut merupakan fatwa yang secara tertulis yang hanya dilakukan oleh lembaga Majelis Ulama Indonesia didalam suatu produk. Maka produk yang sudah tertulis sertifikasi halal sudah sesuai dalam Undang-Undang Pasal 4 yang dimana Jaminnan Produk Halal mengatakan "produk yang telah masuk, kemudian beredar dan diperjual belikan di Wilayah Indonesia harus sudah bersertifikat halal".

Berikut adalah sebuah Undang-Undang yang dimana membahas tentang sertifikasi kehalalan pada suatu produk food, minuman, dan kosmetik :

\section{Undang - Undang No. 18 Tahun 2012}

Didalam Undang - Undang No. I8 tahun 2012 ini menjelaskan tentang pangan, namun didalam Undang - Undang tersebut terdapat pasal ke-97 tentang kehalalan suatu didalam suatu produk. Salah satunya terdapat pada ayat I yang menjelaskan secara rinci bawasannya setiap orang yang melakukan produksi barang pangan didalam Indonesia dan akan diperjual belikan wajib hukumnya memberikan sebuah lebel halal didalam suatu kemasan produk tersebut.

\section{Undang - Undang No. 33 Tahun 2014 Pasal 31}

Didalam Undang - Undang ini menjelaskan secara detail atau secara inti bahwa jika didalam suatu produk terdapat bahan yang dicurigai atau diragukan tentang kehalalan didalam produk tersebut, maka diperlukan untuk melakukan uji laboratoorium.

\section{Undang - Undang No. 33 Tahun 2014 Pasal 33}

Adapun Undang - Undang yang telah dibahas sebelumnya pada bab pendahuluan yakni Undang-Undang Nomor 33 Tahun 2014 yang dimana menjelaskan tentang sebuah jaminan didalam sebuah produk yang sudah halal didalam pasal 33 terdapat didalam ayat I. Daan Undang-Undang tersebut menjelaskan bawasannya sebuah kehalalan yang terdapat didalam 
sebuah produk food, minuman, maupun kosmetik ditetapkan langsung oleh Majelis Ulama Indonesia atau disingkat dengan MUI yang dimana dilakukan sidang fatwa halal.

Dan masih banyak lagi Undang - Undang yang membahas tentang kehalalan suatu produk. Maka dari itu, dengan adanya sebuah jaminan produk halal maka pelaku usaha dapat meningkatkan sebuah nilai tambah untuk memproduksi maupun menjual produknya namun dengan syarat bahan yang digunakan didalam produk halal harus benar-benar syariat Islam $^{20}$. Dengan begitu sebuah produk yang telah memiliki sertifikat halal juga mendapatkan sebuah keuntungan seperti, meningkatnya suatu produk halal didalam daya saing produk-produk dalam bidang global market sehingga memberikan sebuah kontribusi bagi meningkat dan juga didalam pertumbuhan sebuah ekonomi negara.

\section{b) Standarisasi Berdagang Sesuai Etika Bisnis Islam}

Sebuah Etika bisnis Islam sudah hadir sejak jaman nabi Muhammad SAW lahir. dikarenakan Nabi Muhammad SAW dilahirkan hanya untuk menyempurnakan sebuah akhlak, yang dimana didalamnya termasuk dalam hal berbisnis ${ }^{21}$. Sejatinya nabi Muhammad SAW merupakan seoarang pedagang, saat beliau masih berumur I2 tahun beliau memulai usahanya tersebut besrsama pamannya yang bernama $\mathrm{Abu}$ Thalib dengan berjalan kaki ke negeri Syiam kemudian ketika beliau sudah berumur I7 tahun beliau menjalankan usahanya sendirian. Nabi Muhammad SAW berdagang dengan menyebarluaskan agama islam terutama kepada para pedagang Islam.

Karena didalam Al-Qur'an masih terdapat peringatan tentang menyalahgunakan sebuah kekayaan. Pada zaman Rasulullah, islam masih menempatkan sebuah kegiatan perdagangan masih kedalam posisi yang sangat strategis didalam kegiatan manusia

${ }^{20}$ An Ras dan Try Astuti, "Bisnis Halal dalam Perspektif Etika Islam : Kajian Teoritis," Al Ma'arief: Jurnal Pendidikan Sosial I, no. 2 (2019): 97-106.

${ }^{21}$ Adi Putra Patata, "Kesadaran Pelaku Ekonomi Terhadap Etika Bisnis Islam Dalam Islam" (2012).

Volume. IO/No. I/Januari 2022 Al-Iqtishod |3I 


\section{Urgensi Sertifikasi Halal Food ...}

yang mencari rezeki untuk menghidupi kebutuhan hidup. Kemudian Al-Qur'an dan As-Sunnah dipergunakan untuk dasar sebuah etika bisnis dan juga digunakan sebagai teori ekonomi yang digunakan oleh para khalifah. Didalam sebuah etika merupakan sebuah refleksi yang artinya pemikiran sebuah moral. Didalam sebuah etika sebagai refleksi kita berfikir tentang apa yang seharusnya dilakukan maupun yang seharusnya tidak boleh dilakukan ${ }^{22}$. Dan pada umumnya etika dalam bisnis merupakan sebuah nilai-nilai yang paling dasar yang dimana didalam sebuah bisnis dapat berfungsi sebagai penolong untuk para pebisnis didalam hal berdagang yang membantu memecahkan sebuah masalah-masalah tentang moral dalam sebuah praktik bisnis yang mereka (pebisnis) kerjakan.

Oleh sebab itu, untuk mengembangkan sebuah sistem yang menyangkut tentang ekonomi Islam yang membahas tentang upaya sebuah langkah yang memperbaiki atau memberikan hidup kembali untuk suatu hal yang menurutnya paling penting dikarenakan dapat mendapatkan hasil dan juga manfaat yang paling optimal di dalam sebuah perdagangan Islam. Dikarenakan pada perdagangan Islam dinilai sebagai jawaban atas gagalnya sebuah sistem ekonomi baik didalam ekonomi kapitalisme ataupun ekonomi sosialisme. Untuk mendalami sebuah nilai-nilai dasar atau etika bisnis dalam Islam yang dimana didalamnya memabahas tentang perdangangan atau bisnis yang diambil dari Al-Qur'an dan As-Sunnah adalah suatu perilaku yang baik dilakukan. Dengan cara berfikir dengan demikian maka pelaku usaha akan mendapatkan sebuah amalan baik dalam berbisnis.

Sebuah usaha atau sebuah bisnis yang dilakukan dengan cara melanggar sebuah prinsip agama dan juga melanggar etika dalam berbisnis contohnya tidak adanya kejujuran dalam berbisnis, memanipulasi atau meniru produk orang lain, memonopoli perdagangan, dan pemborosan tidak hanya itu manajemen yang tidak memedulikan ataupun tidak menggunakan sebuah penerapan etika atau sebuah nilai-nilai didalam agama dan tergantung pada laba jangka pendek, maka bisnis tidak akan berjalan lancar

${ }^{22}$ Patata. 
dalam jangka panjang. Para penjamin terhadap mutu suatu produk terhadap kehalalannya sangat diperlukan. Oleh karena itu banyaknya sebuah perintah yang harus menegaskan adanya hal itu, baik barang maupun jasa harus menggunakan proses yang sebaik mungkin dikarenakan akan memperoleh hasil yang cukup memuaskan ${ }^{23}$. Sebuah pelanggaran terhadap etika bisnis Islam tersebut dapat juga melemahkan sebuah daya saing dalam bidang industri didalam pasar yang sudah internasional. Hal tersebut dapat terjadi dikarenakan perilaku dara pelaku usaha, yang lebih parahnya lagi jika pelaku usaha yang ada di Indonesia meremehkan suatu etika bisnis yang sangat berlaku secara umum tanpa pengecualian.

Secara umum yang membahas tentang pekerjaan, sesungguhnya Islam tidak membenarkan atau tidak memperbolehkan para umat muslim mencari nafkah atau bekerja untuk mendapatkan uang dengan cara sesuka hatinya seperti halnya, menipu, curang, atau perbuatan-perbuatan yang dapat merugikan diri orang lain. Namun Islam juga memberikan kepada para pelaku usaha yakni sebuah garis pemisah dari yang boleh hingga yang tidak boleh dalam hal mencari sebuah pembekalan hidup dengan cara memberatkan kepada kemaslahatan umum, seperti halnya pembeli dengan pelaku bisnis sama-sama suka sehingga diantara mereka tidak ada yang merasakan kerugian atau dirugikan dan dalam transaksi tersbut tidak ada yang menzalimi maka transaksi tersebut dinyatakan boleh dikarenakan tidak ada yang merasakan kerugian.

Ada pula transaksi yang dilarang oleh Islam atau transaksi yang dimasukkan kedalam kategori dilarang dan dibenci oleh Allah SWT yakni diantaranya ada:

\section{Riba}

Dalam hukum Islam sudah sangat jelas bahwa riba sangat dilarang karena hal tersebut merugikan pihak lain dengan cara memberikan beban (uang) tambahan kepada seseorang yang telah berhutang.

\section{Gharar}

${ }^{23}$ Adin Fadilah, "Etika kegiatan berproduksi” I (2016): I-I2.

Volume. IO/No. I/Januari 2022 A1-Iqtishod|33 


\section{Urgensi Sertifikasi Halal Food ...}

Gharar merupakan transaksi yang tidak memiliki unsur ketidakjelasan tentang produk yang dijual dimana hal tersebut ditujukan untuk merugikan orang lain.

\section{Adanya Perantara (Makelar)}

Pemilik usaha atau pembeli tidak melakukan kegiatan transaksi dipasar atau pembeli memberhentikan pedagang yang seharusnya berjualan dipasar akibatnya harga yang diberikan tidak sesuai dengan harga pasar. Sebuah transaksi yang di lakukan dengan demikian menjadi perhatian yang serius oleh para umat muslim. Dikarenakan sebuah penegakan nilai-nilai moral maupun etika dalam bisnis dalam sebuah kehidupan perdagangan yang dilakukan didalam pasar seharusnya disadari oleh pelaku usaha didalam pasar.

\section{Sesuatu yang Haram}

Didalam Al-Qur'an telah disebutkan apa saja hal-hal ataupun jenis-jenis yang diharamkan seperti memakan daging babi, memperjual belikan babi, bangkai, minum yang dapat memabukkan, dan lain sebagainya. Islam mengharamkan hal tersebut karena berdampak buruk bagi kesehatan serta dapat menimbulkan hal-hal negatif lainnya.

\section{Maysir}

Merupakan sebuah transaksi yang didalamnya terdapat sifat perjudian yang membuat spekulatif-spekulatif bagi para pihak yang terlibat.

Dikarenakan didalam sebuah etika dalam bisnis adalah sebuah moral yang dimana sudah ada dan sudah tertanam didalam hati para pengusaha pasar oleh karena itu etika dalam bisnis adalah sebuah refleksi tentang keimanan kepada Allah SWT jika kita menerapkan etika atau moral tersebut dengan baik atau sesuai ajaran Islam. Para pelaku usaha diperbolehkan berdagang dengan memiliki tujuan memperoleh keuntungan yang besar asalkan berdagang sesuai dengan syariat islam, tidak hanya memiliki tujuan mencari sebuah besar keuntungan yang akan didapat namun juga keberkahan yang akan diperoleh dalam berdagang. 
Untuk mendapatkan sebuah keberkahan dalam hal jual beli, Islam sendiri memiliki sebuah prinsip atau pedoman etika didalam berbisnis atau berdagang:

\section{Jujur dalam segala hal}

Kunci utama dan paling mendasar dalam menjalankan sebuah bisnis ialah kejujuran. Dengan diawali kejujuran disetiap prosesnya maka hasil yang akan didapat akan berjalan dengan maksimal dan tentunya berkah. Namun, jika diawali dengan kebohongan maka hal tersebut tentunya suatu saat nanti akan berdampak negatif bagi usahanya. Seperti halnya seorang pedagang yang berbohong untuk menutupi cacat pada barang yang akan dijualnya dan seorang pembeli membeli barang tersebut. Namun, pada akhirnya pembeli tersebut kecewa akan cacat yang disembunyikan oleh pedagang dan pembeli tersebut tidak ingin membeli barang ditempat itu lagi. Oleh karena itu, kejujuran sangat penting dan merupakan etika yang mendasar bagi pedagang.

\section{Hanya menjual barang-barang yang telah bersertifikat halal}

Sertifikasi halal merupakan salah satu bentuk tanggung jawab dan merupakan nilai etika pedagang untuk tetap melindungi para pembeli dari hal-hal yang diharamkan. Mengonsumsi produk yang halal merupakan hak dari para konsumen terutama pada konsumen muslim, maka dari itu kehalalan dari suatu produk yang diperdagangkan harus jelas baik dari bahan yang didapat hingga memproduksinya.

\section{Tidak memiliki niat untuk bersaing dengan penjual lain dan bersikap adil}

Untung rugi dalam berbisnis merupakan suatu hal yang lumrah maka dari itu sebagai pedagang tentunya harus siap menghadapi semua tantangan dan risiko apapun itu nantinya. Bersaing secara sehat dengan pedagang lain merupakan tindakan yang efektif dibandingkan dengan cara yang tidak sehat seperti memfitnah dagangan mereka ataupun mengambil tindakan yang dapat merugikan pihak lain yang nantinya menimbulkan masalah yang lebih besar.

Volume. IO/No. I/Januari 2022 Al-Iqtishod|35 
Urgensi Sertifikasi Halal Food...

Selain itu, dalam berdagang kita harus bersikap adil baik sesama pedagang lainnya maupun pembeli, karena dalam berdagang kita tidak hanya mementingkan keuntungan semata akan tetapi keberkahan dan ridho dari Allah yang juga akan kita dapatkan.

\section{Sabar dan Murah Hati}

Masalah apapun yang timbul dalam berdagang harus tetap kita terima karena bagaimanapun suatu bisnis tidak selamanya akan berjalan dengan lancar. Akan tetapi tentunya akan ada hambatan baik itu kecil maupun besar sehingga kita dituntut untuk sabar dan murah hati dalam menghadapinya dan mencari solusi yang terbaik untuk menyelesaikannya.

Dari beberapa nilai etika tersebut dapat diterapkan atau dilakukan dalam sebuah kehidupan bermasyarakat di dunia perdagangan yang pastinya akan mendapatkan sebuah keberkahan dan kelancaran dalam menjalankan usahanya.

\section{c) Pentingnya Sertifikasi Halal Food}

Adanya regulasi tentang sertifikasi halal sebuah produk baik makanan, obat-obatan maupun kosmetik merupakan bagian dari perlindungan terhadap konsumen khususnya yang beragama Islam ${ }^{24}$. Ketentuan dalam hukum Islam sendiri telah mengajarkan kita untuk selalu mengkonsumsi sesuatu yang halal. Maka dari itu solusi yang dapat dilakukan oleh produsen agar membantu konsumen mempermudah menentukan produk yang baik untuk mereka beli daan konsumsi ialah dengan adanya sertifikasi halal dalam produk mereka. Sertifikasi halal merupakan suatu bukti yang telah ditetapkan oleh MUI dimana produk yang dipasarkan oleh produsen telah memenuhi semua syarat kehalalannya, sehingga produk tersebut diperbolehkan untuk diperjual belikan di lingkungan masyarakat. Untuk mendapatkan sertifikasi halal harus melalui tahapan yang ketat, dimulai dari awal produk tersebut diproduksi hingga produk

${ }^{24}$ Ramlan dan Nahrowi, "Sertifikasi Halal Sebagai Penerapan Etika Bisnis Islami Dalam Upaya Perlindungan Bagi Konsumen Muslim,” Ahkam XIV, no. I (20I4): I45-54. 
tersebut terjual, itu semua tidak terlepas dari penilaian untuk sampai mendapatkan sertifikasi halal25.

Pemahaman konsep halal pada makanan dan minuman dijelaskan secara komprehensif maka maksud makanan dan minuman halal mencerminkan kebaikan (thayyib) pada setiap aspek lain seperti sehat, bersih, higienis, dan benar secara moral ${ }^{26}$. Oleh karena itu, dengan adanya pencantuman dari sertifikasi label halal pada makanan menjadikan sebagai sarana yang efektif bagi konsumen untuk memilah makanan halal dengan lebih mudah. Selain itu konsumen juga merasa aman, menumbuhkan rasa percaya, dan menghilangkan rasa kekhawatiran mereka terhadap makanan yang akan dibeli dan dikonsumsi karena sudah terjamin kehalalannya.

Setiap produsen harus memenuhi kebutuhan dan hak konsumen, termasuk konsumen Muslim sebagai tanggung jawab produsen untuk produk yang dibawanya ke dalam peredaran yang menimbulkan kerugian atau ketidak nyamanan konsumen ${ }^{27}$. Pelaksanaan perlindungan konsumen terkait kehalalan produk diatur melalui UU Nomor 8 Tahun 1999 tentang Perlindungan Konsumen dan PP Nomor 69 Tahun 1999 tentang Label dan Iklan Pangan yang salah satu pasalnya mengatur kewajiban produsen untuk memeriksakan kehalalan produknya terlebih dahulu sebelum mencantumkan label "halal" pada produknya ${ }^{28}$. Dengan adanya peraturan perlindungan terhadap konsumen maka, konsumen tidak perlu khawatir karena mereka dapat melaporkan pihak produsen atas ketidaknyamanan yang terjadi bahkan saat terjadinya sebuah penyelewengan terhadap suatu produk yang mereka konsumsi. Adapun kelebihan dari adanya label halal pada suatu produk yaitu:

\footnotetext{
${ }^{25}$ Warto dan Samsuri, "Sertifikasi Halal dan Implikasinya Bagi Bisnis Produk Halal di Indonesia."

${ }^{26}$ Hendri Hermawan Adinugraha dan Ahmad Hasan Asy’ari Ulama’i, "Halal Lifestyle Di Indonesia," AnNisbah: Jurnal Ekonomi Syariah 05, no. 2 (2019): 57-8I.

${ }^{27}$ Muchtar Ali, "Konsep Makanan Halal Dalam Tinjauan Syariah Dan Tanggung Jawab Produk Atas Produsen Industri Halal,” Ahkam XVI, no. 2 (20I6): 29I-306.

${ }^{28}$ Nidya Waras Sayekti, "Jaminan Produk Halal Dalam Perspektif Kelembagaan (Warranty of Halal Product of Institutional Perspective),” Jurnal Ekonomi \& Kebijakan Publik 5, no. 2 (2014): 193-209.
}

Volume. IO/No. I/Januari 2022 Al-Iqtishod|37 
Urgensi Sertifikasi Halal Food ...

\section{Kelebihan terdapat label halal pada produk makanan.}

a. Lebih banyak peminat terutama pada konsumen muslim.

Penduduk muslim di dunia cukup besar dan tentunya hal tersebut menjadi peluang besar pula bagi para pembisnis karena dalam hukum Islam diwajibkan untuk mengkonsumsi makanan yang jelas kehalalannya dan pastinya konsumen muslim sadar akan hal tersebut, sehingga mereka akan pilih-pilih makanan sesuai dengan kehalalannya.

b. Lebih aman, sehat, dan terjamin halalnya.

Dengan adanya label dan sertifikasi halal tentunya sudah melalui proses pengawasan yang terjamin sesuai dengan peraturan hukum dinegara sehingga aman dan tentunya terjamin serta terhindar dari hal hal yang menyeleweng dan haram.

c. Peluang bersaingnya lebih besar.

Pencantuman dari sertifikasi halal pada suatu produk makanan tidak hanya untuk kepentingan konsumen saja, akan tetapi bagi pihak produsen hal tersebut merupakan suatu keuntungan yang memiliki nilai lebih dari berbisnis. Hal itu dikarenakan dengan adanya pencantuman label halal pada kemasan produk dapat membuat peluang produk tersebut dipersaingan pasar akan lebih tinggi, dibandingkan dengan produk makanan tanpa adanya sertifikasi halalnya. Serta dapat pula para produsen bersaing di dalam pasar global muslim, dimana kesempatan tersebut cukup besar dan dapat bersaing dengan negara-negara lainnya karena hal itu tidak terlepas dari jumlah penduduk muslim di dunia yang cukup besar.

d. Mendapatkan kepercayaan dari pihak konsumen.

Kepercayaan dalam suatu kegiatan bisnis merupakan poin yang utama karena dengan konsumen percaya pada produk kita dan tentunya dengan kehalalan yang terjamin maka mereka akan selalu membeli produk yang kita produksi. 
Meskipun begitu masih cukup banyak produsen yang kurang akan kesadaran pentingnya sebuah label halal pada produk mereka terutama pada produsen kecil. Banyak juga produk pangan yang mencantumkan label halal tetapi belum mendapatkan sertifikat halal, yang artinya pencantuman label halal hanya berdasarkan inisiatif produsen semata ${ }^{29}$. Namun tindakan dari produsen tersebut tidak dibenarkan, karena prosedur yang benar dalam pemberian izin terhadap sertifikasi label halal pada suatu produk ialah oleh MUI sesuai dengan ketetapan hukumnya. Hal ini lah yang menjadikan salah satu kelemahan dan tantangan di industri pangan Indonesia, karena cukup banyak produsen dan konsumen menganggap sertifikasi label makanan halal tidaklah terlalu penting. Mereka beranggapan sertifikasi halal hanya dijadikan sebagai pelengkap saja bukan dijadikan sebagai kewajiban. Untuk mengantisipasi kekhawatiran sebagian masyarakat yang memiliki pandangan demikian, MUI yang mempunyai kewenangan melakukan sertifikasi seharusnya melakukan kontrol yang ketat dan berkelanjutan terhadap produk makanan, terutama yang sudah tersertifikasi ${ }^{30}$.

Seiring dengan berkembangnya industri pangan serta banyaknya edukasi-edukasi mengenai halal life membuat para konsumen mulai sadar akan pentingnya sertifikasi halal pada suatu produk dan lebih selektif dalam mengambil keputusan. Kampanye halal life di media sosial dan elektronik membuat muslim melek terhadap sertifikasi halal produk, sehingga sangat efektif mendorong para pengusaha mengembangkan industri dan pasar halal ${ }^{31}$. Hal ini pula sebagai upaya memberikan perlindungan bagi kepentingan konsumen dengan adanya kepastian hukum. Kepastian hukum itu meliputi segala upaya berdasarkan atas hukum untuk memberdayakan konsumen

\footnotetext{
${ }^{29}$ Yasmirah Mandasari, "Sanksi Pidana Terhadap Kandungan Non Halal Terhadap Produk Makanan Bersertifikat Halal Yang Dilakukan Korporasi,” Soumatera Law Review 2, no. 2 (2019): 258-69.

${ }^{30}$ Nurul Huda, "Pemahaman Produsen Makanan Tentang Sertifikasi Halal (Studi Kasus di Surakarta)," Ishraqi I0, no. I (2012): I-I3.

${ }^{31}$ Pratiwi Subianto, "Rantai Nilai Dan Perspektif Kesadaran Masyarakat Muslim Akan Makanan Halal," Conference On Islamic Management Accounting And Economics (CIMAE) 2 (2018): I4I-46.
}

Volume. IO/No. I/Januari 2022 Al-Iqtishod|39 


\section{Urgensi Sertifikasi Halal Food ...}

memperoleh atau menentukan pilihannya atas barang dan/atau jasa kebutuhannya serta mempertahankan atau membela hak-haknya apabila dirugikan oleh perilaku pelaku usaha penyedia kebutuhan konsumen ${ }^{32}$.

\section{E. Simpulan}

Dari pemaparan diatas dapat disimpulkan bahwa sertifikasi label halal food dalam suatu produk makanan sangatlah penting terutama bagi konsumen muslim, dimana hal tersebut merupakan bentuk salah satu saranan komunikasi yang efektif antara produsen dan konsumen. Hukum Islam mewajibkan kita untuk mengkonsumsi sesuatu yang halal baik melalui awal proses pembuatan hingga pendistribusiannya. Oleh karena itu, pemerintah memberikan wadah bagi para produsen untuk mendapatkan hak mereka dalam membuat sertifikasi halal dalam produknya serta perlindungan hukum bagi konsumen. Namun, masih banyak pula dari mereka yang beranggapan sertifikasi halal tidak terlalu penting dan hanya dijadikan sebagai pelengkap saja. Maka dari itu, kesadaran diri mengenai pentingnya sebuah sertifikasi halal perlu ditingkatkan kembali hingga mampu dijadikan sebagai pendorong tercapainya sebuah kemaslahatan bersama baik oleh konsumen maupun produsen.

\section{F. Daftar Pustaka}

Adinugraha, H. H., \& Ulama’ i, A. H. A. (2019). Halal Lifestyle Di Indonesia. AnNisbah: Jurnal Ekonomi Syariah, 05(2), 57-8I.

Ali, M. (2016). Konsep Makanan Halal Dalam Tinjauan Syariah Dan Tanggung Jawab Produk Atas Produsen Industri Halal. Ahkam, XVI(2), 29I-306.

Amalia, F. (20I4). Etika Bisnis Islam: Konsep Dan Implementasi Pada Pelaku Usaha Kecil. Al-Iqtishad: Jurnal Ilmu Ekonomi Syariah, 6(I), II6-I25.

Assifa, S. N., Suprihatin, T., \& Eprianti, N. (2020). Tinjauan Prinsip Etika Bisnis Islam pada Strategi Pemasaran di Restoran Royal Kashimura Bandung. Prosiding Hukum EKonomi Syariah, 6(2), 205-208.

\footnotetext{
32 Yakin, "Pencantuman Label Halal (Halal Food) Etika Dalam Bisnis Dan Perlindungan Konsumen."
} 
Aulia Hosanna, M., \& Adi Nugroho, S. (20I4). Pelaksanaan UU Nomor 33 Tahun 2014 Tentang Jaminan Produk Halal. Hukum Adigama.

Fadilah, A. (2016). Etika kegiatan berproduksi. I, I-I2.

Fikriawan, S. (2018). Sertifikasi Halal Di Indonesia: (Analisis Kuasa Simbolik dalam Kontestasi Fatwa Majelis Ulama Indonesia). el Barka: Journal of Islamic Economics and Business, OI(OI), 27-52.

Hasan, K. S. (2013). Kepastian Hukum Sertifikasi Dan Labelisasi Halal Produk Pangan. Dinamika Hukum, I4(I00), 227-238.

Huda, N. (2012). Pemahaman Produsen Makanan Tentang Sertifikasi Halal (Studi Kasus di Surakarta). Ishraqi, IO(I), I-I3.

Izzuddin, A. (2018). Pengaruh Label Halal. Kesadaran Halal Dan Bahan Makanan Terhadap Minta Beli Makanan Kuliner. Jurnal Penelitian Ipteks, 3(2), I00-I I4.

Juliyani, E. (2016). Etika Bisnis Dalam Persepektif Islam. Jurnal Ummul Qura, $V I I(I), 63-74$.

Mandasari, Y. (2019). Sanksi Pidana Terhadap Kandungan Non Halal Terhadap Produk Makanan Bersertifikat Halal Yang Dilakukan Korporasi. Soumatera Law Review, 2(2), 258-269.

Patata, A. P. (2012). Kesadaran Pelaku Ekonomi Terhadap Etika Bisnis Islam Dalam Islam.

Putri, E. A. (202I). Kewenangan MUI Pasca Terbitnya PP No. 31 Tahun 2019 Tentang Peraturan Pelaksanaan UU No. 33 Tahun 2014 Tentang Jaminan Produk Halal. I5(2), 333-350.

Rahmawati. (2017). Etika Bisnis Islam Pada Pedagang Makanan (Studi Kasus di Keude Blang Jreum, Aceh). Jurnal JESKaPe, I(I), I09-I36.

Ramlan, \& Nahrowi. (20I4). Sertifikasi Halal Sebagai Penerapan Etika Bisnis Islami Dalam Upaya Perlindungan Bagi Konsumen Muslim. Ahkam, XIV(I), I45I54.

Volume. I0/No. I/Januari 2022 A1-Iqtishod |4I 
Urgensi Sertifikasi Halal Food ...

Ras, A., \& Astuti, T. (2019). Bisnis Halal dalam Perspektif Etika Islam : Kajian Teoritis. Al Máarief: Jurnal Pendidikan Sosial, I(2), 97-I06.

Sakti, M., R, D. A., \& W, Y. yuli. (20I5). Perlindungan konsumen terhadap beredarnya makanan yang tidak bersertifikat halal. Yuridis, 2(I), 62-77.

Sayekti, N. W. (20I4). Jaminan Produk Halal Dalam Perspektif Kelembagaan (Warranty of Halal Product of Institutional Perspective). Jurnal Ekonomi \& Kebijakan Publik, 5(2), 193-209.

Subianto, P. (2018). Rantai Nilai Dan Perspektif Kesadaran Masyarakat Muslim Akan Makanan Halal. Conference On Islamic Management Accounting And Economics (CIMAE), 2, I4I-I46.

Warto, \& Samsuri. (2020). Sertifikasi Halal dan Implikasinya Bagi Bisnis Produk Halal di Indonesia. Al Maal: Joumal of Islamic Economics and Banking, 2(I), 98-II2.

Yakin, A. (2018). Pencantuman Label Halal (Halal Food) Etika Dalam Bisnis Dan Perlindungan Konsumen. Ekomadania, 2(I), 24-34. 